\title{
Heavy Metal Analyses and Nutritional Composition of Raw and Smoked Fishes from Ologe and Lagos Lagoon, Lagos, Nigeria
}

\section{"JOLAOSO, ANUOLUWAPO OMOSILEOLA, NJOKU, KELECHI LONGINUS, AKINOLA, MODUPE OLATUNDE, ADESUYI, ADEOLA ALEX, ADEDOKUN, ADERINOLA HANNAH}

Environmental Biology Research Unit, Cell Biology and Genetics Department, University of Lagos, Akoka, Lagos, Nigeria "Corresponding Email: anujolaoso@gmail.com

\begin{abstract}
This study was conducted to evaluate nutritional composition and heavy metals concentration of smoked and raw edible fish species from Ologe lagoon (freshwater) and Lagos lagoon (marine). The fish species from Ologe include: Chrysichthys nigrodigitatus (Catfish), Monodactylus sebae (African moony), Pomadasys jubelini (Buro), Sphyraena barracuda (Great barracuda), and Pseudotolithus elongatus (Croaker), while that of Lagos lagoon include Chrysichthys nigrodigitatus (Catfish), Caranx hippos (Crevalle jack), Liza falcipinnis (Sicklefin mullet), Pomadasys jubelini (Buro), and Monodactylus sebae (African moony). The nutritional composition ranged in the following trend moisture $(43.24-76.79 \%)>$ carbohydrate $(3.16-$ $63.45 \%)>$ protein $(0.80-31.55 \%)>$ fibre $(1.07-2.8 \%)>$ ash $(0.81-1.88 \%)>$ fat $(0.40-$ $1.30 \%$ ). In this study, these fishes are generally low in fats (lean fish), and fish smoking tend to reduces their nutritional composition. Heavy metals concentration trend thus $\mathrm{Zn}(2.4-7.75$ $\mathrm{mg} / \mathrm{kg})>\mathrm{Ni}(0.80-1.925 \mathrm{mg} / \mathrm{kg})>\mathrm{Cr}(0.20-0.550 \mathrm{mg} / \mathrm{kg})>\mathrm{Pb}(0.025-0.50 \mathrm{mg} / \mathrm{kg})$. In all the samples, all the metals of interest were detected except cadmium which was not found in any of the samples analysed. $\mathrm{Pb}(0.025-0.5 \mathrm{mg} / \mathrm{kg})$ values in the fishes were lower than the maximum standard level reported to be $0.5 \mathrm{mg} / \mathrm{kg}$ dry weight by FAO except in the raw Pomadasys jubelini where the value is $0.5 \mathrm{mg} / \mathrm{kg}$. The fresh water fishes showed higher concentration of heavy metals than marine water fishes but not statistically significant $(p>0.05)$. Although, smoked fishes showed higher concentration of heavy metals than the raw fishes, it was only significant for zinc $(\mathrm{p}<0.05)$. In view of this study and the importance of fish in human diet, it is recommended that biological monitoring of fishes meant for consumption from these two water bodies be carried out regularly to ensure human safety. (C) JASEM
\end{abstract}

\section{http://dx.doi.org/10.4314/jasem.v20i2.7}

KEYWORDS: Nutritional composition, heavy metals, fresh water fishes, marine water fishes, lagoons.

\section{Introduction}

Fish is an important component in the diets of many Nigerians. It is a good source of protein for humans and animals (Holma and Maalekuu, 2013). Over 32,000 species of fish have been described, making them the most diverse group of vertebrates, however, only a small number of species are commonly eaten by humans (Le've^que et al., 2008). Fish is also an important source of poly-unsaturated fatty acids and also contains omega-3, calcium, iodine, phosphorous, iron, trace elements like copper and a fair proportion of the B vitamins known to support good health (Tucker, 1997; USDA, 2010). Nutritionists recommend that human should eat fish every day (Sutharshiny and Sivashanthini, 2011). An increasing amount of evidences suggest that, fish and fish oil (contain high amount of polyunsaturated fatty acids) are valuable in decreasing the serum cholesterol to prevent a number of coronary heart diseases and increase neurological development (Turkmen et al. 2005). Eating of fish can reduce the risk of heart diseases and lower the risk of developing dementia, including Alzheimer's diseases (Kelly and Knopman, 2008). Fish contains significantly low lipids and higher water than beef or chicken and is favoured over other white or red meals (Grant, 1997).

In Nigeria, fish is either eaten fresh, fried or smoked, and form a much cherished delicacy that cut across socio-economic, age, religions and educational barriers (Adebayo et al., 2008). According to the study of Adekoya and Miller (2004), marine fish is generally cheaper and more abundant when compared with fresh water fishes, which are relatively more expensive in Nigeria. The major constituents of fish are moisture, protein and fat with minerals occurring in trace amount (Holland et al., 1993). Fish mineral and metal contents may vary according to the surrounding 
environment (Ogundiran et al., 2014). Pollution of the aquatic environment by inorganic chemicals has been considered a major threat to water quality and the aquatic organisms including fishes. Their direct toxicity to man and aquatic organisms and the indirect toxicity through their accumulations in the aquatic food chain are issues of serious concern (Adesuyi et al., 2016).

These environmental pollutants such as heavy metals cause serious health and environmental risk because of their persistence, toxicity at low concentration and ability to incorporate into food chain of aquatic organism (Harte et al, 1991), and fish are generally considered to be the most relevant organisms for pollution monitoring in aquatic ecosystems (Vander Oost et al., 2003). Therefore despite fish nutritional value, its consumption can bring a potential hazard concern to the consumers.

It has been observed that different processing methods have different effects on the nutritional compositions of fish species. This is because heating, freezing and exposure to high concentration of salt lead to chemical and physical changes and therefore digestibility is increased, due to protein denaturation, but the content of thermolabile compounds and polyunsaturated fatty acids is often reduced (Chukwu and Shaba, 2009). The objective of this study is to investigate the proximate and heavy metal composition of some raw and smoked selected fresh water and marine fishes from Ologe and Lagos Lagoon.

\section{MATERIALS AND METHODS}

Sample collection: The fish samples used for this study were obtained from fishermen at the landing sites in Ologe lagoon (freshwater) and Lagos lagoon (marine) and preserved in ice during transport to the laboratory. The fishes were virtually of the same size as variability in size stands to affect the proximate composition and the mineral elements concentration. Fish samples were identified at the Aquaculture unit of Marine Science department and analysed at the central research laboratories of University of Lagos Akoka, Lagos.

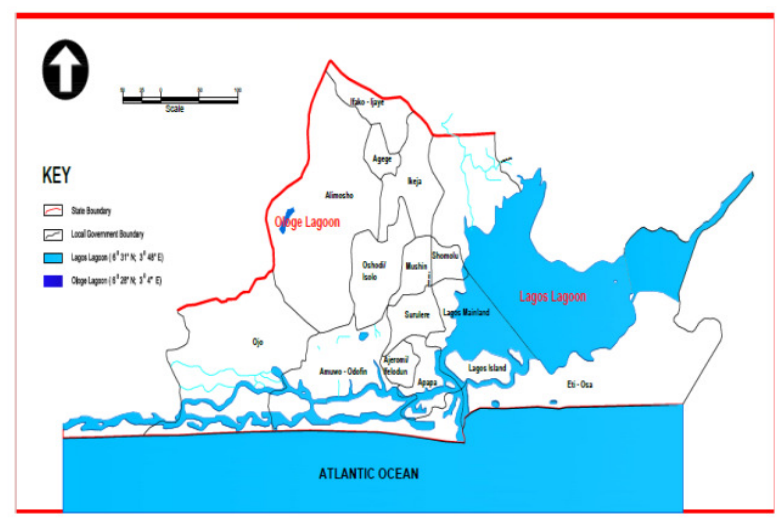

Fig 1: Map showing sample locations

Sample preparation: The fish samples were thoroughly washed with tap water and distilled water to remove any adhering contaminants and drained under folds of filter paper. A representative sample from each species from both marine and fresh water was then smoked with wood. Each species of fish (raw and smoked) was dissected with a knife and the intestines, guts and bones were removed separately. The tissue samples were then homogenized separately into a fine mesh with an electric food blender and thereafter, stored in a deep freezer at $-18^{\circ} \mathrm{C}$ prior to digestion.

Heavy metal analyses: The tissues were oven dried at 70 to $73^{\circ} \mathrm{C}$ until constant weight was obtained. The specimens were then ground to fine powder and stored in desiccators in order to avoid moisture accumulation before digestion. The digestion procedure was carried out as described by Kotze et al. (2006). Twenty milliliter $(20 \mathrm{ml})$ of concentrated nitric acid $(55 \%)$ and $10 \mathrm{ml}$ of perchloric acid $(70 \%)$ was added to approximately $1 \mathrm{~g}$ tissue (dry mass) in a $100 \mathrm{ml}$ Erlenmeyer flask. The digestion was done on a hotplate $\left(200\right.$ to $\left.250^{\circ} \mathrm{C}\right)$ until the solutions were clear. The solutions were then filtered through an acid resistant $0.45 \mathrm{~mm}$ filter paper and made up to $50 \mathrm{ml}$ each with distilled water. The samples were stored in clean glass bottles prior to the determination of the metal concentration by Atomic Absorption Spectrophotometer (AAS).

Stock standard was prepared by dividing the molar mass of the compound of the element by the molar mass of the element. The standard solution prepared was used to calibrate Atomic Absorption Spectrophotometer (AAS). The prepared sample was aspirated into the AAS; the air, the fuel of the instrument (acetylene) and the sample, formed aerosol inside the AAS. About $10 \%$ of the aerosol goes into the flame and $90 \%$ passed out as waste. The flame 
vaporized, dissociated, and atomized the sample from ground state to excited state.

The readings were taken from the equipment in $\mathrm{mg} / \mathrm{g}$ and the results were converted to $\mathrm{mg} / \mathrm{kg}$ which is the actual concentration of the metal in the sample using the equation (Aderinola, et al., 2009):

$$
=\frac{\text { concentration of metal }}{\text { weight of sample }}
$$

Proximate Analysis: Determination of Moisture Content (\%): Moisture content was determined according to the method of AOAC (2005). An empty clean crucible was weighed; $5 \mathrm{~g}$ of the fresh or smoked sample was weighed into a crucible and dried in an oven at $105^{\circ} \mathrm{C}$ to constant weight. The moisture content was then calculated using this equation:

$$
\text { Moisture } \%=\frac{\text { wet weight }- \text { dry weight }}{\text { wet weight of sample }} \times 100
$$

Determination of Total Ash (\%): Ash content of fish was determined according to the method of AOAC (2005). An empty clean crucible was weighed; $5 \mathrm{~g}$ of sample was weighed into the crucible and ashed in a furnace at $550^{\circ} \mathrm{C}$ to a constant weight. Total ash was then calculated thus;

$$
\text { Ash } \%=\frac{\text { weight of ash }}{\text { weight of sample }} \times 100
$$

Determination of Fat (\%): Crude fat was obtained by exhaustively determined method of AOAC (2005). $5 \mathrm{~g}$ of sample was massed into a polypropylene centrifuge bottle. Sodium acetate, aliquots of methanol, chloroform and water was added into the bottle and shaken for 30 minutes. The content of the bottle were centrifuged at $2500 \mathrm{rpm}$ for $10 \mathrm{~min}$, after which it was to set in $25^{\circ} \mathrm{C}$ water bath for 15 minutes. The samples were evaporated to dryness under nitrogen blanket, heated in a drying oven for 30 minutes, and cooled in a desiccator for at least 30 minutes. Fat content was then determined using;

$$
\text { Fat } \%=\frac{(W 2-W 1)}{(V A \times S W)} \times V c \times 100
$$

Where, $\mathrm{W}_{2}$ was the weight of glass tube and dried extract $(\mathrm{g}), \mathrm{W}_{1}$ was the weight of empty dried glass tube $(\mathrm{g})$, Vc was the total volume of chloroform $(\mathrm{ml})$, VA was the volume of extract dried $(\mathrm{ml})$, and SW was the weight of the sample in grammes.

Determination of Protein (\%): Crude protein content of fish was determined according to the method of AOAC (2000). Briefly, $1 \mathrm{~g}$ of sample was weighed into digestion tubes. Two Kjeltabs $\mathrm{Cu} 3.5$ (catalyst salts) were added into each tube. About $20 \mathrm{ml}$ of concentrated sulphuric acid $\left(\mathrm{H}_{2} \mathrm{SO}_{4}\right)$ was carefully added into the tube and then shaken gently. Digestion procedure was carried out. Digested samples were cooled for 10 to $20 \mathrm{~min}$. Distillation procedure was then performed using distillation unit and the distillate was titrated with $0.025 \mathrm{~N}$ sulphuric acid $\left(\mathrm{H}_{2} \mathrm{SO}_{4}\right)$ until the end point changes from green to pink. Volume of acid required in the titration was recorded. Blank was prepared with the exclusion of sample. The percentage of protein content was calculated according to the following equation:

$$
\begin{gathered}
\% \text { Nitrogen }=\frac{0.014 \times V D \times N \times 100 \times T V}{\text { weight of sample } \times A D} \\
\% \text { Protein }=\% N \times F
\end{gathered}
$$

Where, VD is the Volume of digest; $\mathrm{N}$ is the normality of acid; TV is the titre value; $\mathrm{AD}$ is the aliquot of digest and $\mathrm{F}$ is the conversion factor for nitrogen to protein (6.25).

Determination of Fibre: Fibre content was determined according to the method of AOAC (2005). $5 \mathrm{~g}$ of each fish sample was weighed into a 1 liter conical flask. Then $200 \mathrm{ml}$ of boiling sulphuric acid was added and boiled for 30 minutes over a burner. Swirling is done occasionally to remove solids from adhering to the sides of the flask. The hot solution was decanted through Buchner funnel fitted with Whatman 52 filter paper. All residues were rinsed with boiling water until no colour change in litmus paper to be sure acid has been removed. Then the residue was transferred into a $200 \mathrm{ml}$ of $1.25 \%$ $\mathrm{NaOH}$ solution into a 1liter flask and brought to boil and maintained a gentle ebullition for 30 minutes and filtered through rapid hardened filter paper. $1 \%$ $\mathrm{HCl}$ and distilled water, $15 \mathrm{ml}$ of alcohol and $10 \mathrm{ml}$ of diethyl ether were also added. The sample was dried in an oven at $100{ }^{\circ} \mathrm{C}$ for 1 hour and allowed to cool in a desiccator and weighed $\left(\mathrm{W}_{1}\right)$. Sample was put in a crucible in a furnace at $55^{\circ} \mathrm{C}$ for 3-4 hours; it was cooled in a desiccator and weighed again $\left(\mathrm{W}_{2}\right)$. Fibre was calculated thus:

$$
\% \text { Fibre }=\frac{W 1-W 2}{\text { weight of the sample }} \times 100
$$

Determination of Carbohydrate (\%): Carbohydrate content was calculated based on difference calculation (AOAC, 2005):

$$
\begin{aligned}
\text { Carbohydrate }= & 100 \%-(\% \text { moisture }+\% \text { ash } \\
& +\% \text { crude protein }+\% \text { fat })
\end{aligned}
$$

Statistical Analyses: Analysis of the data was carried out using the excel worksheet package and Graph pad prism, version 6.0 .

\section{RESULTS AND DISCUSSION} *JOLAOSO, ANUOLUWAPO OMOSILEOLA, NJOKU, KELECHI LONGINUS, AKINOLA, MODUPE
OLATUNDE, ADESUYI, ADEOLA ALEX, ADEDOKUN, ADERINOLA HANNAH 
Nutritional composition of fish samples: Table 1 shows the values for the proximate composition of the sampled fish species. The highest moisture content was found in Liza falcipinnis with value of $76.79 \%$ while the lowest was recorded for Monodactylus sebae with $43.24 \%$. Generally, the moisture content for the smoked fishes was quite lower than the fresh unprocessed fishes, and it was statistically significant $(p<0.05)$. The moisture contents in all the three species common to the two habitats were around the acceptable level (60-80\%), which could be due to the stable water levels in the habitats the fishes were collected (Adewumi et al., 2014). Moisture contents of a fish are also a good indicator of its relative content of energy, protein and lipid (Olagunju et al. 2012). According to Holma and Maalekuu (2013), smoking, salting and frying have been observed to reduce moisture content of fishes, hence, low moisture content of smoked fishes in this study. Moisture content in all the species agreed with observation of Daniel (2015), Ogundiran et al. (2014) and Olagunju et al. (2012) in several marine and freshwater fish species.

Smoked Pseudotolithus elongatus have the highest content ash content $(1.88 \%)$ among all sampled fishes (marine and freshwater) while the least was obtained in smoked Monodactylus sebae $(0.81 \%)$. There was variation in ash content of both raw and smoked fishes, and marine and freshwater fishes; however, they were not statistically significant ( $\mathrm{p}>0.05)$. Ash is a measure of the mineral content of food item; it is the inorganic residue that remains after the organic matter has been burnt off (Adewumi et al., 2014). The range of ash in this study suggests that these species of fishes are good source of minerals such as calcium, potassium, zinc, iron and magnesium.

For the protein content of the fishes, smoked Sphyraena barracuda had the highest value of $31.58 \%$ while the least value of $0.80 \%$ was recorded for smoked Monodactylus sebae. Crude protein content for marine fishes was in the order, Sphyraena barracuda $>$ Pomadasys jubelini $>$ Pseudotolithus elongatuss $>$ Chrysichthys nigrodigitatus > Monodactylus sebae. Crude protein content for freshwater fishes was in the order; Chrysichthys nigrodigitatus $>$ Pomadasys jubelini $>$ Caranx hippos $>$ Liza falcipinnis > Monodactylus sebae. Protein content of smoked fishes was quite higher than the raw fishes from both environment and it was statistically insignificant $(\mathrm{p}>0.05)$. Fishes from the freshwater environment are significantly more proteinous than marine fishes $(\mathrm{p}<0.05)$. The protein content from all sampled fishes from both Ologe and Lagos lagoon was high. It shows that all the fish species are good sources of protein. The relatively high to moderate percentage crude protein may be attributed to the fact that fishes are good source of pure protein, but the variations observed in values obtained could also be as a result of fish age, habitat, fish consumption or absorption capability and conversion potentials of essential nutrients from their diets or their local environment into such biochemical attributes needed by the organisms body (Adewoye and Omotosho, 1997). Smoked fishes in this experiment, recorded higher crude protein content than the raw fishes and this was in accordance with the findings of Chukwu (2009) and Kumolu-Johnson (2010). The significant increase suggests that protein nitrogen was not lost during drying and thus increase in crude protein level can best be explained thus, smoking resulted in concentrating crude protein components of red fish, (KumoluJohnson, 2010). And this concentration effect is basically as a result of loss of moisture by the smoked fish as opined by Koral et al., (2009).

For fats, raw Chrysichthys nigrodigitatus contained the highest fat content of $1.30 \%$, while the least was observed in smoked Pseudotolithus elongatus with $0.40 \%$. The degree of variation between the two habitats is low and there was no significant difference ( $p>0.05$ ). Fish can be grouped into four categories according to their fat contents: lean fish $(<2 \%)$, low fat $(2-4 \%)$, medium fat $(4-8 \%)$ and high fat $(>8 \%)$ (Ackman, 1989). Hence, based on these categories the fish species can be classified as low fat fishes (lean fishes). Keremah and Amakiri (2013) equally reported low values of fats for Chrysichthys nigrodigitatus obtained in Yenagoa (2.13\%). However, this result is at variance with Chrysichthys nigrodigitatus (10.62\%) obtained from Cross River, Nigeria as reported by Daniel (2015). Traditional method of fish preservation, smoking and salting have been implicated to reduce crude fat content of fishes due to oxidation and crude fat break down into other components; oxidation of poly-unsaturated fatty acids (PUFA) contained in the fish tissue to products such as peroxides, aldehydes, ketones and the free fatty acids (Holma and Maalekuu, 2013). Hence, low crude fat content of smoked fish in this study.

The fiber content ranged from $1.07 \%$ in raw Liza falcipinnis from Ologe freshwater environment to 2.80 $\%$ in smoked Monodactylus sebae. The increase in the crude fibre content of smoked fishes could be accounted for by oxidation of their poly-unsaturated fatty acids (PUFA) components, contained in their tissues to products such as peroxides, aldehydes, ketones and free fatty acids (Daramola et al., 2007).

*JOLAOSO, ANUOLUWAPO OMOSILEOLA, NJOKU, KELECHI LONGINUS, AKINOLA, MODUPE OLATUNDE, ADESUYI, ADEOLA ALEX, ADEDOKUN, ADERINOLA HANNAH 
Table 1: Nutritional composition of raw and smoked fishes (\%)

\begin{tabular}{|c|c|c|c|c|c|c|c|}
\hline \multicolumn{2}{|l|}{ Lagos lagoon (Marine) } & \multirow{2}{*}{$\begin{array}{l}\text { Moisture } \\
63.57\end{array}$} & \multirow{2}{*}{$\begin{array}{l}\text { Ash } \\
0.89\end{array}$} & \multirow{2}{*}{$\begin{array}{l}\text { Protein } \\
13.23\end{array}$} & \multirow{2}{*}{$\begin{array}{l}\text { Fat } \\
0.92\end{array}$} & \multirow{2}{*}{$\begin{array}{c}\text { Fiber } \\
1.10\end{array}$} & \multirow{2}{*}{$\begin{array}{l}\text { Carbohydrate } \\
12.92\end{array}$} \\
\hline Chrysichthys & smoked & & & & & & \\
\hline megroatgilains & raw & 70.94 & 1.38 & 12.28 & 1.30 & 1.45 & 20.02 \\
\hline & Mean & $67.26 \pm 3.69$ & $1.14 \pm 0.25$ & $12.76 \pm 0.48$ & $1.11 \pm 0.19$ & $1.28 \pm 0.18$ & $16.47 \pm 3.55$ \\
\hline & Std. Dev. & 5.21 & 0.35 & 0.67 & 0.27 & 0.25 & 5.02 \\
\hline \multirow{4}{*}{ Monodactylus sebae } & smoked & 20.96 & 1.09 & 19.90 & 0.97 & 1.10 & 33.70 \\
\hline & & 43.24 & 1.71 & 11.34 & 1.09 & 1.45 & 63.45 \\
\hline & Mean & $32.1 \pm 11.14$ & $1.40 \pm 0.31$ & $15.62 \pm 4.28$ & $1.03 \pm 0.06$ & $1.28 \pm 0.175$ & $48.58 \pm 14.88$ \\
\hline & Std. Dev. & 15.75 & 0.44 & 6.05 & 0.085 & 0.248 & 21.04 \\
\hline \multirow[t]{4}{*}{ Pomadasys jubelini } & smoked & 52.59 & 1.35 & 17.04 & 0.93 & 1.14 & 8.51 \\
\hline & raw & 71.03 & 1.82 & 19.95 & 0.53 & 1.82 & 23.30 \\
\hline & Mean & $61.81 \pm 9.22$ & $1.59 \pm 0.24$ & $18.50 \pm 1.46$ & $0.73 \pm 0.20$ & $1.48 \pm 0.34$ & $15.91 \pm 7.40$ \\
\hline & Std. Dev. & 13.04 & 0.33 & 2.06 & 0.28 & 0.48 & 10.46 \\
\hline \multirow[t]{4}{*}{ Sphyraena barracuda } & smoked & 54.48 & 1.18 & 31.58 & 0.50 & 1.09 & 6.53 \\
\hline & raw & 59.12 & 1.86 & 20.78 & 0.61 & 1.90 & 20.37 \\
\hline & Mean & $56.80 \pm 2.32$ & $1.52 \pm 0.34$ & $26.18 \pm 5.4$ & $0.56 \pm 0.056$ & $1.50 \pm 0.41$ & $13.45 \pm 6.92$ \\
\hline & Std. Dev. & 3.28 & 0.48 & 7.64 & 0.078 & 0.573 & 9.79 \\
\hline \multirow{4}{*}{$\begin{array}{l}\text { Pseudotolithus } \\
\text { elongatuss }\end{array}$} & smoked & 72.97 & 1.88 & 18.80 & 0.40 & 1.60 & 3.16 \\
\hline & raw & 74.16 & 1.08 & 16.82 & 0.62 & 1.88 & 6.62 \\
\hline & Mean & $73.57 \pm 0.60$ & $1.48 \pm 0.40$ & $17.81 \pm 0.99$ & $0.51 \pm 0.11$ & $1.74 \pm 0.14$ & $4.89 \pm 1.73$ \\
\hline & Std. Dev. & 0.84 & 0.57 & 1.40 & 0.16 & 0.19 & 2.45 \\
\hline \multicolumn{8}{|c|}{ Ologe lagoon (Freshwater) } \\
\hline \multirow{4}{*}{$\begin{array}{l}\text { Chrysichthys } \\
\text { nigrodigitatus }\end{array}$} & smoked & 67.21 & 1.10 & 18.80 & 0.93 & 1.20 & 3.58 \\
\hline & raw & 74.39 & 1.32 & 24.11 & 0.61 & 1.92 & 4.84 \\
\hline & Mean & $70.80 \pm 3.60$ & $1.21 \pm 0.11$ & $21.46 \pm 2.66$ & $0.77 \pm 0.16$ & $1.56 \pm 0.36$ & $4.21 \pm 0.63$ \\
\hline & Std. Dev. & 5.08 & 0.16 & 3.76 & 0.23 & 0.51 & 0.89 \\
\hline \multirow[t]{4}{*}{ Monodactylus sebae } & smoked & 67.40 & 0.81 & 0.80 & 0.91 & 2.80 & 21.98 \\
\hline & raw & 70.18 & 1.29 & 3.33 & 1.20 & 2.60 & 29.71 \\
\hline & Mean & $68.79 \pm 1.39$ & $1.05 \pm 0.24$ & $2.07 \pm 1.27$ & $1.06 \pm 0.15$ & $2.70 \pm 0.10$ & $25.85 \pm 3.87$ \\
\hline & Std. Dev. & 1.97 & 0.34 & 1.79 & 0.21 & 0.14 & 5.47 \\
\hline \multirow[t]{4}{*}{ Pomadasys jubelini } & smoked & 60.16 & 1.37 & 22.44 & 0.71 & 1.33 & 7.21 \\
\hline & raw & 66.94 & 1.29 & 23.28 & 1.00 & 1.60 & 12.68 \\
\hline & Mean & $63.55 \pm 3.39$ & $1.33 \pm 0.04$ & $22.86 \pm 0.42$ & $0.86 \pm 0.15$ & $1.47 \pm 0.14$ & $9.95 \pm 2.74$ \\
\hline & Std. Dev. & 4.79 & 0.06 & 0.59 & 0.21 & 0.19 & 3.87 \\
\hline \multirow[t]{4}{*}{ Caranx hippos } & smoked & 70.20 & 1.70 & 25.73 & 0.39 & 1.48 & 4.10 \\
\hline & raw & 66.67 & 1.00 & 20.43 & 0.69 & 1.41 & 6.20 \\
\hline & Mean & $68.44 \pm 1.77$ & $1.35 \pm 0.35$ & $23.08 \pm 2.65$ & $0.54 \pm 0.15$ & $1.45 \pm 0.04$ & $5.15 \pm 1.05$ \\
\hline & Std. Dev. & 2.49 & 0.50 & 3.75 & 0.21 & 0.05 & 1.49 \\
\hline \multirow[t]{4}{*}{ Liza falcipinnis } & smoked & 76.70 & 1.40 & 21.60 & 0.65 & 1.11 & 4.45 \\
\hline & raw & 76.79 & 1.01 & 13.30 & 0.65 & 1.07 & 7.27 \\
\hline & Mean & $76.75 \pm 0.05$ & $1.21 \pm 0.20$ & $17.45 \pm 4.15$ & $0.65 \pm 0.0$ & $1.09 \pm 0.02$ & $5.86 \pm 1.41$ \\
\hline & Std. Dev. & 0.06 & 0.28 & 5.87 & 0.0 & 0.03 & 1.99 \\
\hline
\end{tabular}

The highest carbohydrate content was present in the raw sample of Monodactylus sebae and the lowest content was observed in the smoked sample of Pseudotolithus elongatus with $63.45 \%$ and $3.16 \%$ respectively. There was a significant difference in carbohydrate content of both the smoked and the raw fishes $(\mathrm{p}<0.05)$. The appreciable values of carbohydrate could be due to the presence of elements like calcium and potassium in their diets (Adewoye and Omotosho, 1997).
Heavy metal concentrations in sampled fishes: The heavy metal contents of the fishes are shown in Table 2. Heavy metal content of the fish samples varied in their concentrations both within and between the selected species sampled (smoked or raw and marine or freshwater). The highest concentration of $\mathrm{Pb}$ was detected in raw Pomadasys jubelini with concentration of $0.50 \mathrm{mg} / \mathrm{kg}$ and the lowest concentration of 0.025 $\mathrm{mg} / \mathrm{kg}$ was detected in the raw Monodactylus sebae and the smoked Sphyraena barracuda. There was little variation in $\mathrm{Pb}$ concentration in fishes from both

\section{"JOLAOSO, ANUOLUWAPO OMOSILEOLA, NJOKU, KELECHI LONGINUS, AKINOLA, MODUPE OLATUNDE, ADESUYI, ADEOLA ALEX, ADEDOKUN, ADERINOLA HANNAH}


environments (either raw or smoked) and it was not statistically significant $(\mathrm{p}>0.05)$. Lead is nonessential element and a great threat to life if present in substantial quantity. It is toxic even at low concentrations and has no known function in biochemical processes (Burden et al., 1998). The $\mathrm{Pb}$ values were quite high in the fishes as $\mathrm{Pb}$ maximum standard level was reported to be $0.5 \mathrm{mg} / \mathrm{kg}$ dry weight (FAO, 1983).

Zinc has the highest concentration among the metals in this study. It ranged between $2.4 \mathrm{mg} / \mathrm{kg}$ in raw Chrysichthys nigrodigitatus obtained from Lagos lagoon to $7.75 \mathrm{mg} / \mathrm{kg}$ in raw Pomadasys jubelini from Ologe lagoon. In this study smoking of fish has a contributory effect on the zinc concentration in fishes as it increases its bioconcentration. Zinc is among the essential elements, serves as cofactors to some important enzymes and also involved in most metabolic pathway in humans and its deficiency can lead to loss of appetite, growth retardation, skin changes and immunological abnormalities; however, at higher concentration they tend to be toxic (Fawole et al., 2013). Fish takes up $\mathrm{Zn}$ directly from water, especially via mucous and gills. The values of $\mathrm{Zn}$ obtained were significantly high in Pomadasys jubelini, Liza falcipinni, and Monodactylus sebae but lower than the $50 \mathrm{mg} / \mathrm{kg}$ maximum zinc level permitted for fish according to Food Codex. The values of $\mathrm{Zn}$ in this study are higher than the value recorded in the tissues of Oreochromis niloticus from Ologe lagoon by Kumolu-Johnson and Ndimele (2012).

Nickel concentration of fish species from both Ologe and Lagos lagoon ranged $0.80 \mathrm{mg} / \mathrm{kg}$ in smoked Sphyraena barracuda to $1.925 \mathrm{mg} / \mathrm{kg}$ in smoked Monodactylus sebae. Cadmium was not detected in any of the fish samples from both Ologe and Lagos lagoon. The highest concentration of $\mathrm{Cr}$ was detected in smoked Pomadasys jubelini $(0.550 \mathrm{mg} / \mathrm{kg})$ while the least was detected in raw Pomadasys jubelini $(0.20$ $\mathrm{mg} / \mathrm{kg}$ ). Chromium is an abundant element in the earth crust and it occurs in oxidation states ranging from $\mathrm{Cr}^{2+}$ to $\mathrm{Cr}^{6+}$. Only $\mathrm{Cr}^{3+}$ and $\mathrm{Cr}^{6+}$, however, are of biological importance (Majolagbe et al., 2012). Industrial effluent discharged a major source of chromium followed by urban runoff. Chromium toxicity is because of acute exposure of elevated levels of chromium in the environment and this is associated with cancer of respiratory tract (Norseth, 1981; Majolagbe et al., 2012). The concentration of $\mathrm{Cr}$ in this study is quite and significantly higher than the values reported in some previous studies in fishes of Ologe Lagoon and other water bodies in Nigeria (KumoluJohnson and Ndimele, 2012). However, the $\mathrm{Cr}$ values were all below Food and Agricultural Organisation (1983) limit of $0.15-1.0 \mathrm{mg} / \mathrm{kg}$.

Table 2: Heavy metal concentrations of smoked and fresh marine fishes

\begin{tabular}{|c|c|c|c|c|c|c|}
\hline Lagos lagoon (marine) & & $\mathrm{Pb}(\mathrm{mg} / \mathrm{kg})$ & $\mathrm{Cr}(\mathrm{mg} / \mathrm{kg})$ & $\mathrm{Cd}(\mathrm{mg} / \mathrm{kg})$ & $\mathrm{Zn}(\mathrm{mg} / \mathrm{kg})$ & $\mathrm{Ni}(\mathrm{mg} / \mathrm{kg})$ \\
\hline Chrysichthys & Smoked & 0.150 & 0.275 & ND & 2.450 & 1.675 \\
\hline nigrodigitatus & Raw & ND & 0.225 & ND & 2.400 & 1.550 \\
\hline \multirow[t]{2}{*}{ Monodactylus sebae } & Smoked & ND & 0.500 & ND & 5.075 & 1.925 \\
\hline & Raw & ND & 0.225 & ND & 4.925 & 1.750 \\
\hline \multirow[t]{2}{*}{ Pomadasys jubelini } & Smoked & 0.025 & 0.250 & ND & 7.600 & 1.550 \\
\hline & Raw & 0.050 & 0.200 & ND & 6.975 & 1.725 \\
\hline \multirow[t]{2}{*}{ Sphyraena barracuda } & Smoked & 0.025 & 0.400 & ND & 4.400 & 0.800 \\
\hline & Raw & ND & 0.425 & ND & 4.275 & 1.000 \\
\hline \multirow[t]{2}{*}{ Pseudotolithus elongatus } & Smoked & ND & 0.325 & ND & 4.725 & 1.175 \\
\hline & Raw & ND & 0.375 & ND & 4.475 & 1.025 \\
\hline \multicolumn{7}{|l|}{ Ologe lagoon (freshwater) } \\
\hline Chrysichthys & Smoked & 0.050 & 0.550 & ND & 3.600 & 1.300 \\
\hline nigrodigitatus & Raw & 0.125 & 0.475 & ND & 3.450 & 1.150 \\
\hline Monodactylus sebae & Smoked & 0.100 & 0.350 & ND & 3.675 & 0.900 \\
\hline
\end{tabular}




\begin{tabular}{lllllll}
\hline & Raw & 0.025 & 0.250 & ND & 3.775 & 1.800 \\
Pomadasys jubelini & Smoked & ND & 0.550 & ND & 7.525 & 1.300 \\
& Raw & 0.500 & 0.500 & ND & 7.750 & 1.000 \\
Caranx hippos & Smoked & ND & 0.250 & ND & 3.650 & 1.775 \\
& Raw & ND & 0.225 & ND & 3.475 & 1.675 \\
Liza falcipinnis & Smoked & ND & 0.300 & ND & 5.500 & 1.825 \\
& Raw & ND & 0.400 & ND & 4.975 & 1.875 \\
& & & & & & \\
\hline
\end{tabular}

*ND-not detected

Conclusion: Traditional process of fish preservation such as smoking has the capacity to reduce nutritional composition of fishes and also bioconcentrate heavy metals in fishes. In view of the importance of fish in human diet, it is necessary that biological testing and monitoring of the fish meant for consumption should be carried out regularly to ensure human safety and health. WHO (1995) reported that heavy metals must be controlled in food sources in order to assure public safety. Increased concentration of food heavy metals is associated with the etiology of a number of diseases, especially cardiovascular, renal, neurological and bone diseases. This study showed that fishes from both marine and freshwater bioaccumulate heavy metals and smoking process can add to the concentration level of these heavy metals in fishes.

Acknowledgements: Many thanks to Dr. Emmanuel and Miss Ajibola of Marine department who helped in identification of fish samples and also accompanying me on field trips to the lagoons.

\section{REFERENCE}

Ackman, RG (1989). Nutritional composition of fats in seafoods. Progress in Food Nutrition Science. $13: 161-241$.

Adebayo, BC; Onilude, AA; Patrick, UG (2008). Mycofloral of smoke-dried fishes sold in Uyo, Eastern Nigeria. World Journal of Agricultural Sciences, 4(3):346-350.

Adekoya, BB; Miller, JW (2004). Fish cage culture potential in Nigeria - An overview. National Cultures. Agriculture Focus, 1(5):10.

Aderinola, OJ; Clarke, EO; Olarinmoye, OM; Kusemiju, V; Anetekhai, MA (2009). Heavy metals in surface water, sediments, fish and periwinkles of Lagos Lagoon. American-
Eurasian Journal of Agricultural and Environmental Sciences. 5(5): 609-617.

Adesuyi, AA; Ngwoke, MO; Akinola, MO; Njoku, KL; Jolaoso, AO (2016). Physicochemical Assessment of Sediments from Nwaja Creek, Niger Delta, Nigeria. Journal of Geoscience and Environment Protection, 4:16-27.

Adewoye, SO; Omotosho, JS (1997). Nutrient Composition of some freshwater Fishes in Nigeria. BioScience Research Community, 11(4): 333-336.

Adewumi, AA; Adewole, HA; Olaleye, VF (2014). Proximate and elemental composition of the fillets of some fish species in Osinmo Reservoir, Nigeria. Agriculture and biology journal of North America, 5(3): 109-117.

AOAC (2000). Official Methods of Analysis. 17th ed. Gaithersburg, Maryland, USA, AOAC International.

Burden, VM; Sandheinrich, MB; Caldwell, CA (1998). Effects of lead on the growth and alpha aminolevulinic acid dehydrates activity of juvenile rainbow trout, Oncorhynchus mykiss. Environmental Pollution, 101: 285-289.

Chukwu, O; Shaba, IM (2009). Effects of Drying Methods on Proximate Compositions of Catfish (Clarias gariepinus). World Journal of Agricultural Sciences, 5(1): 114-116.

Chukwu, O (2009). Influences of Drying Methods on Nutritional Properties of Tilapia Fish (Oreochromis niloticus). World Journal of Agricultural Science, 5 (2): 256-258. 
Daniel, IE (2015). Proximate Composition of Three Commercial Fishes Commonly Consumed in Akwa Ibom State, Nigeria. International Journalof Multidisciplinary Academic Research, 3(1):9-13.

Daramola, JA; Fasakin, EA; Adeparusi, EO (2007). Changes in Physicochemical and Sensory Characteristics of Smoke-Dried Fish Species Stored At Ambient Temperature. African Journal of Food Agriculture Nutrition and Development): 7 (6). www.biolone.org.br/nd (Assessed on 7th February, 2016).

FAO (1983). Compilation of legal limits for hazardous substances in fish and fishery products, Food and Agricultural Organization, Fishery circular No. 464, pp. 5-100.

Fawole, OO; Yekeen, TA; Adewoye, SO; Ogundiran, MA; Ajayi, OE; Nwaiya, MN (2013). Nutritional qualities and trace metals concentration of six fish species from Oba reservoir, Ogbomoso, Nigeria. African Journal of Food Science, 7(8): 246-252.

Grant, WB (1997). Dietary links to Alzheimer's disease. Alzheimer's Disease Review. 2: 42-55.

Harte, J; Holdren, C; Schneider, R; Shirley, C (1991). Toxics A to Z, A guide to Everyday Pollution Hazards. University of California Press, Oxford, England. 478pp.

Holland, B; Brown, J; Buss, DH (1993). Fish and fish products; the third supplement to McCance and Widdowson's "The composition of foods" 5th edition, HMSO, London.

Holma, KA; Maalekuu, BK (2013). Effect of traditional fish processing methods on the proximate composition of red fish stored under ambient room conditions. American Journal of Food and Nutrition, 3(3):73-82.

Kelly, BJ; Knopman, DS (2008). Alternative medicine and Alzheimer disease. Neurologist 14(5):299306.

Keremah RI; Amakiri, G (2013). Proximate composition of nutrients in fresh adult catfishes: Chrysichthys nigrodigitatus, Heterobranchus bidorsalis and Clarias gariepinus in Yenagoa, Nigeria. Greener Journal of Agricultural Sciences, 3 (4): 291-294.
Koral, S; Köse, S; Tufan, B (2009). Investigating the Quality Changes of Raw and Hot Smoked Garfish (Belone belone euxini, Günther, 1866) at Ambient and Refrigerated Temperatures. Turkish Journal of Fisheries and Aquatic Sciences, 9:53-58

Kotze, PD; Preez, HH; Van-Vuren, JHJ (2006). Bioaccumulation of copper and Zinc in Oreochromis mossambicus and Clarias gariepinus, from the Olifants River, Mpumalanga, South Africa. Dept. of Zoology, Rand Afrikans University press ISSN 0378-4738. Water SA Vol. 25 No. 1, South Africa.

Kumolu-Johnson CA; Ndimele, PE (2012). Some Aspects of the Limnology and Heavy Metal Content of Water, Sediment and Oreochromis niloticus (Linnaeus, 1758) from Ologe Lagoon, Lagos, Nigeria. Research Journal of Environmental Toxicology, 6:210-221.

Kumolu-Johnson, CA; Aladetohun, NF; Ndimele, PE (2010). The effects of smoking on the nutritional qualities and shelf-life of Clarias gariepinus. African Journal of Biotechnology 9(1): 073-076.

Le've^que, C; Oberdorff, T; Paugy, D; Stiassny, JLM; Tedesco, AP (2008). Global diversity of fish (Pisces) in freshwater. Hydrobiologia. 595:545567.

Majolagbe, AO; Osibanjo, O; Yussuf, KA; Olowu, RA (2012). Trace Metals Distribution and Contamination in the Surface Marine Sediments of Roro Bay in Lagos, Nigeria. Chemistry Journal, 2(2): 69-78.

Norseth, P (1981) Carcinogenicity of chromium. Environmental Health Perspectives, 40 (2): 121301.

Ogundiran, MA; Adewoye, SO; Ayandiran, TA; Dahunsi, SO (2014). Heavy metal, proximate and microbial profile of some selected commercial marine fish collected from two markets in south western Nigeria. African Journal of Biotechnology, 13(10): 1147-1153.

Olagunju, A; Muhammad, A; Mada, SB; Mohammed, A; Mohammed, HM; Mahmoud, KT (2012). Nutrient Composition of Tilapia zilli, Hemisynodontis membranacea, Clupea harengus and Scomber Scombrus Locally Consumed in Africa. World Journal of Life Sciences and Medical Research; 2:16-19.

\section{*JOLAOSO, ANUOLUWAPO OMOSILEOLA, NJOKU, KELECHI LONGINUS, AKINOLA, MODUPE OLATUNDE, ADESUYI, ADEOLA ALEX, ADEDOKUN, ADERINOLA HANNAH}


Sutharshiny, S; Sivashanthini, K (2011). Total lipid and cholesterol content in the flesh of the five important commercial fishes from waters around Jaffna Peninsula, Sri Lanka. Int J. Biol. Chem. 6: 161-169.

Tucker, BW (1997). Overview of current seafood nutritional issues: formation of potentially toxic products. In: Shahidi, et.al (ed.), Seafood safety, processing and biotechnology. Lancaster, USA. pp. 5-10.
Database for standard reference, Release 23. Nutrient laboratory.

Vander Oost, R; Beyer., J; Vermeulen, NPE (2003). Fish bioaccumulation and biomarkers in environmental risk assessment. Environ. Toxico. Phar. 13: 57-149.

WHO (1995). Lead Environmental Health Criteria. WHO, Geneva.

Turkmen, AM; Turkmen, YT; Akyurt, I (2005). Heavy metals in three commercially valuable fish species from Iskenderun Bay, Northern East Mediterranean Sea, Turkey. Food Chem. 91:167-172.

USDA (2010). US Department of Agriculture, Agricultural Research Service, National Nutrient *JOLAOSO, ANUOLUWAPO OMOSILEOLA, NJOKU, KELECHI LONGINUS, AKINOLA, MODUPE OLATUNDE, ADESUYI, ADEOLA ALEX, ADEDOKUN, ADERINOLA HANNAH 